\title{
Decatecholaminisation during sepsis
}

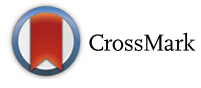

\author{
Alain Rudiger ${ }^{1 *}$ (D) and Mervyn Singer ${ }^{2}$
}

Sepsis is defined as life-threatening organ dysfunction caused by a dysregulated host response to infection [1]. The syndrome is characterised by autonomic dysfunction and increased plasma levels of noradrenaline and adrenaline [2]. These catecholamines originate mainly from the activated sympathetic nervous system, but also originate from the adrenal gland, gut, and immune cells [3]. While necessary and life-saving in the early fight or flight reaction to any insult, prolonged adrenergic stress is detrimental and contributes to organ dysfunction [4]. Strategies to reduce adrenergic stress have been proposed (Table 1) under the umbrella term decatecholaminisation.

Esmolol (Table 2) is a short-acting cardioselective beta-1 adrenergic blocker which has been tested in septic animals and in preliminary studies in human sepsis [5]. In the largest trial to date, Morelli et al. [6] enrolled septic shock patients with tachycardia ( $>95$ beats $/ \mathrm{min}$ ) and an ongoing requirement for high-dose norepinephrine despite $24 \mathrm{~h}$ of active resuscitation. In this high-risk population (28-day mortality of $80.5 \%$ in the control group), esmolol titrated to control heart rate was both safe and efficacious, reducing mortality to $49.4 \%$. The observed decrease in norepinephrine requirements could be mediated by a blunted immune response, resulting in an improved microcirculation [7], or enhanced adrenergic receptor sensitivity [8].

Dexmedetomidine is a highly selective alpha-2 adrenoreceptor agonist that has sedative, anxiolytic, and opioid-sparing effects (Table 2) [9, 10]. The use of dexmedetomidine in critically ill patients increased ventilator-free time [11] and decreased the incidence of postoperative complications, delirium, and mortality up to 1 year post-cardiac surgery [12]. In postoperative patients, dexmedetomidine provided sympatholytic activity [13]. It also offers anti-inflammatory and organ protective effects in animal models [14]. The use of dexmedetomidine as an anti-adrenergic strategy in sepsis has been evaluated in a recently completed multicentre Japanese study ('DESIRE', https://clinicaltrials.gov/ct2/show/NCT01760967; last accessed 28 August 2016) for which results are still eagerly awaited.

In this issue of Critical Care, Hernandez et al. [15] tested both esmolol and dexmedetomidine in a sheep model of endotoxic shock with systemic hypotension, pulmonary hypertension, and hyperlactataemia. After a brief phase of fluid resuscitation and haemodynamic stabilisation with norepinephrine, animals were randomised to receive dexmedetomidine, esmolol, or placebo. Despite the early use of sympatholytic drugs, systemic and regional haemodynamics were maintained in the interventional groups compared to the control group over the 2-h study period. Although heart rate was significantly reduced by esmolol, cardiac output, mean arterial pressure, noradrenaline requirements, and $\mathrm{SvO}_{2}$ did not differ from placebotreated animals. Dexmedetomidine reduced serum adrenaline levels by almost $40 \%$. Both esmolol and dexmedetomidine reduced arterial and portal vein lactate levels and improved lactate clearance. In summary, both drugs were well tolerated from a haemodynamic point of view and associated with likely beneficial effects on metabolism.

These observations are particularly interesting as dexmedetomidine and esmolol were started very early after shock induction. However, the short duration of the study precludes knowledge of longer term effects and any impact on outcomes. Furthermore, it would have been fascinating to have a fourth experimental group exploring possible synergism between esmolol and dexmedetomidine, as a rationale could be argued for the use of both. Certainly it is premature to translate these findings to clinical practice in septic patients, but this work should encourage further research into the role of alpha-2 agonists in sepsis, with or without beta-blockade.

\footnotetext{
* Correspondence: alain.rudiger@usz.ch

${ }^{1}$ Institute of Anaesthesiology, University Hospital Zurich, Raemistrasse 100, CH 8091 Zurich, Switzerland

Full list of author information is available at the end of the article
} 
Table 1 Decatecholaminisation strategies for patients with septic shock

\begin{tabular}{|c|c|c|}
\hline & Strategy & Recommendations \\
\hline \multirow{8}{*}{$\begin{array}{l}\text { Blunt endogenous catecholamine release; } \\
\text { avoid compensatory adrenergic stimulation }\end{array}$} & \multirow{3}{*}{$\begin{array}{l}\text { Optimize cardiac preload and } \\
\text { vascular filling }\end{array}$} & Assess fluid status by leg-raise test \\
\hline & & Perform repetitive fluid challenges to a target (e.g. stroke volume) \\
\hline & & Use cardiac output monitoring and/or echocardiography \\
\hline & \multirow{2}{*}{$\begin{array}{l}\text { Treat hypoxia and severe } \\
\text { anaemia }\end{array}$} & Target oxygen saturation between 92-96 \% \\
\hline & & Transfuse red blood cells if haemoglobin falls below $70 \mathrm{~g} / \mathrm{l}$ \\
\hline & \multirow{3}{*}{$\begin{array}{l}\text { Optimize sedation and } \\
\text { analgesia }\end{array}$} & Avoid over-sedation; use sedation targets \\
\hline & & $\begin{array}{l}\text { Interrupt sedation daily, especially if long-lasting sedatives } \\
\text { (e.g. midazolam) are used }\end{array}$ \\
\hline & & Use dexmedetomidine (see text for details) \\
\hline \multirow[t]{5}{*}{ Reduce exogenous catecholamine administration } & $\begin{array}{l}\text { Avoid excessive beta-mimetic } \\
\text { stimulation }\end{array}$ & $\begin{array}{l}\text { Use cardiac output monitoring and/or echocardiography } \\
\text { Avoid supra-normal physiological targets }\end{array}$ \\
\hline & $\begin{array}{l}\text { Only use inotropes if } \\
\text { contractility is impaired }\end{array}$ & Use cardiac output monitoring and/or echocardiography \\
\hline & Consider alternative drugs & $\begin{array}{l}\text { Consider alternative inotropes (e.g. levosimendan) and } \\
\text { vasopressors (e.g. vasopressin) }\end{array}$ \\
\hline & $\begin{array}{l}\text { Accept abnormal physiological } \\
\text { values }\end{array}$ & Adjust therapeutic targets \\
\hline & $\begin{array}{l}\text { Consider beta-blockers if } \\
\text { tachycardia persists }\end{array}$ & $\begin{array}{l}\text { Prefer short-acting drugs (e.g esmolol, see text) that can be } \\
\text { stopped if adverse effects occur }\end{array}$ \\
\hline \multirow{4}{*}{$\begin{array}{l}\text { Blunt inflammatory response (to reduce cardiac } \\
\text { depression and microvascular dysfunction) }\end{array}$} & \multirow[t]{2}{*}{ Treat underlying infection } & Use intravenous antibiotics (after sampling for microbiology) \\
\hline & & Push for urgent surgical/interventional source control \\
\hline & \multirow[t]{2}{*}{ Reduce cytokine load } & Consider low-dose steroids \\
\hline & & Consider extra-corporeal cytokine removal \\
\hline
\end{tabular}

Evidence and class of recommendations vary between the different interventions

Table 2 Pharmacological properties of the study drugs

\begin{tabular}{|c|c|c|}
\hline & Dexmedetomidine & Esmolol \\
\hline Characteristics & Highly selective alpha-2 adrenoreceptor agonist & Short-acting, selective beta-1 blocker \\
\hline Mode of action & $\begin{array}{l}\text { Acts centrally, predominantly in the brain stem } \\
\text { (sedation) and in the spinal cord (analgesia) }\end{array}$ & Acts peripherally, predominantly in the heart \\
\hline \multirow[t]{4}{*}{ Effects } & \multirow{2}{*}{$\begin{array}{l}\text { Short- and long-term sedation in the intensive } \\
\text { care unit setting }\end{array}$} & Negative chronotropic, dromotropic, inotropic effects \\
\hline & & Improves ventricular filling by prolonging diastole \\
\hline & Anxiolysis; opioid-sparing effect; anti-delirant effects & \multirow[t]{2}{*}{ Sympatholytic activity } \\
\hline & Sympatholytic activity & \\
\hline Route of administration; dose & $\begin{array}{l}\text { Intravenous infusion: } 0.2-1.4 \mu \mathrm{g} / \mathrm{kg} / \mathrm{h} \text { Loading } \\
\text { dose not recommended in clinical practice }\end{array}$ & $\begin{array}{l}\text { Infusion: } 25 \mathrm{mg} / \mathrm{h} \text {, up-titration every } 20 \mathrm{~min} \text { in increments } \\
\text { of } 50 \mathrm{mg} / \mathrm{h} \text {, to reach the target heart rate of <95beats/min }\end{array}$ \\
\hline \multirow[t]{3}{*}{ Pharmacokinetics } & Half-life: $1.5 \mathrm{~h}$ & Half-life: 9 min \\
\hline & Degradation by hepatic metabolism & Degradation by unspecific esterases \\
\hline & No dose adjustments in renal dysfunction & No dose adjustment in renal and/or hepatic dysfunction \\
\hline \multirow[t]{3}{*}{ Adverse haemodynamic effects } & Hypotension: 25 \%, serious $1.7 \%$ & Symptomatic hypotension: $12 \%$ \\
\hline & Hypertension: 15 \% & \multirow{2}{*}{$\begin{array}{l}\text { Haemodynamic deterioration in patients with compensatory } \\
\text { tachycardia }\end{array}$} \\
\hline & Bradycardia: $13 \%$, serious $0.9 \%$ & \\
\hline
\end{tabular}




\section{Funding}

Departmental funds.

\section{Authors' contributions}

AR and MS drafted the manuscript and reviewed the final version of the text. Both authors read and approved the final manuscript.

\section{Competing interests}

AR received lecture fees and travel expenses from Orion Pharma $\mathrm{GmbH}$ (distributor of dexmedetomidine), Baxter Healthcare SA, Amomed Pharma $\mathrm{GmbH}$, and OrphaSwiss $\mathrm{GmbH}$ (distributors of esmolol). MS has received lecture fees and sat on advisory boards for Baxter Healthcare SA and Orion Pharma GmbH.

\section{Author details}

'Institute of Anaesthesiology, University Hospital Zurich, Raemistrasse 100, CH 8091 Zurich, Switzerland. ${ }^{2}$ Bloomsbury Institute of Intensive Care Medicine, University College London, London WC1E 6BT, UK.

\section{Published online: 04 October 2016}

\section{References}

1. Singer M, Deutschman CS, Seymour CW, Shankar-Hari M, Annane D, Bauer M, Bellomo R, Bernard GR, Chiche JD, Coopersmith CM, et al. The Third International Consensus Definitions for Sepsis and Septic Shock (Sepsis-3). JAMA. 2016:315:801-10.

2. Annane D, Trabold F, Sharshar T, Jarrin I, Blanc AS, Raphael J-C, Gajdos P. Inappropriate sympathetic activation at onset of septic shock: a spectral analysis approach. Am J Respir Crit Care Med. 1999;160:458-65.

3. Rudiger $A$, Singer $M$. The heart in sepsis: from basic mechanisms to clinical management. Curr Vasc Pharmacol. 2013;11:187-95.

4. Andreis DT, Singer M. Catecholamines for inflammatory shock: a Jekyll-andHyde conundrum. Intensive Care Med. 2016;42:1387-97.

5. Rudiger A. Beta-block the septic heart. Crit Care Med. 2010;38:S608-12

6. Morelli A, Ertmer C, Westphal M, et al. Effect of heart rate control with esmolol on hemodynamic and clinical outcomes in patients with septic shock: a randomized clinical trial. JAMA. 2013:310:1683-91.

7. Morelli A, Donati A, Ertmer C, Rehberg S, Kampmeier T, Orecchioni A, D'Egidio A, Cecchini V, Landoni G, Pietropaoli P, et al. Microvascular effects of heart rate control with esmolol in patients with septic shock: a pilot study. Crit Care Med. 2013;41:2162-8.

8. Reeves RA, Boer WH, DeLeve L, Leenen FH. Nonselective beta-blockade enhances pressor responsiveness to epinephrine, norepinephrine, and angiotensin II in normal man. Clin Pharmacol Ther. 1984;35:461-6.

9. Keating GM. Dexmedetomidine: a review of its use for sedation in the intensive care setting. Drugs. 2015;75:1119-30.

10. Cruickshank M, Henderson L, MacLennan G, Fraser C, Campbell M, Blackwood B, Gordon A, Brazzelli M. Alpha-2 agonists for sedation of mechanically ventilated adults in intensive care units: a systematic review. Health Technol Assess. 2016:20:1-118.

11. Reade MC, Eastwood GM, Bellomo R, Bailey M, Bersten A, Cheung B, Davies A, Delaney A, Ghosh A, van Haren F, et al. Effect of dexmedetomidine added to standard care on ventilator-free time in patients with agitated delirium: a randomized clinical trial. JAMA. 2016;315:1460-8.

12. Ji F, Li Z, Nguyen H, Young N, Shi P, Fleming N, Liu H. Perioperative dexmedetomidine improves outcomes of cardiac surgery. Circulation. 2013:127:1576-84

13. Talke P, Richardson CA, Scheinin M, Fisher DM. Postoperative pharmacokinetics and sympatholytic effects of dexmedetomidine. Anesth Analg. 1997:85:1136-42.

14. Hofer S, Steppan J, Wagner T, Funke B, Lichtenstern C, Martin E, Graf BM, Bierhaus A, Weigand MA. Central sympatholytics prolong survival in experimental sepsis. Crit Care. 2009;13:R11.

15. Hernandez G, Tapia P, Alegria L, et al. Effects of dexmedetomidine and esmolol on systemic hemodynamics and exogenous lactate clearance in early experimental septic shock. Crit Care. 2016;20:234. 